\title{
Tracer signals of the intermediate layer of the Arabian Sea
}

\author{
Monika Rhein, Lothar Stramma, and Olaf Plähn
}

\begin{abstract}
In 1995, hydrographic and chlorofluorocarbon (CFCs, components F11, F12) measurements were carried out in the Gulf of Aden, in the Gulf of Oman, and in the Arabian Sea. In the Gulf of Oman, the F12 concentrations in the Persian Gulf outflow (PGW) at about $300 \mathrm{~m}$ depth were significantly higher than in ambient surface water with saturations reaching $270 \%$. These high values could not be caused by air-sea gas exchange. The outflow was probably contaminated with oil, and the lipophilic character of the CFCs could then lead to the observed supersaturations. The intermediate F12 maximum decreased rapidly further east and south. At the Strait of Bab el Mandeb in the Gulf of Aden, the Red Sea outflow (RSW) was saturated with F12 to about $65 \%$ at $400 \mathrm{~m}$ depth, and decreased to $50 \%$ while descending to $800 \mathrm{~m}$ depth. The low saturation is not surprising, because the outflow contains deep and intermediate water masses from the Red Sea which were isolated from the surface for some time. The tracer contributions to the Arabian Sea for Indian Central Water (ICW) and PGW are about equal, while below $500 \mathrm{~m}$ depth the RSW contribution greatly exceeds ICW. Modeling the CFC budget of the Arabian Sea, the inflow of ICW north of $12^{\circ} \mathrm{N}$ is estimated to be 1 $6 \mathrm{~Sv}$, depending mainly on the strength of the flow of Red Sea Water into the Arabian Sea.
\end{abstract}

\section{Introduction}

The intermediate depths of the Arabian Sea north of $12^{\circ} \mathrm{N}$ are characterized by the thickest low oxygen layer in the ocean today [Olson et al., 1993]. Three water masses determine the properties of this layer: The outflows from the Persian Gulf (PGW) and from the Red Sea (RSW), and the northward propagation of Indian Central Water (ICW). A detailed description of the hydrographic characteristics can be found in Wyrtki [1973], Siedler, [1968], Quadfasel and Schott, [1982], and Fischer et al., [1996]. There is little information available on the renewal, recirculation and mixing of the Arabian Sea waters in this intermediate layer.

Here, the CFC, oxygen, and hydrographic data sampled on three RV 'Meteor' cruises in 1995 (Figure 1) are combined with our data from a RV 'Sonne' cruise in August 1993 (Figure 1), and data from 1987 [Olson et al., 1993] to characterize the tracer properties of these intermediate water masses.

In our research area, the CFC concentrations decrease exponentially from the upper 50 to $100 \mathrm{~m}$ to about

Institut für Meereskunde an der Universität Kiel, Kiel, Germany

Copyright 1997 by the American Geophysical Union.

Paper number 97GL01041.

0094-8534/97/97GL-01041\$05.00
$1000 \mathrm{~m}$ depth. In the northern Indian Ocean no deep and bottom water masses are formed and the CFC signals of the Antarctic Bottom Water and North Atlantic Deep Water carried within the Circumpolar Deep Water have not reached the region yet. The depth of the CFC detection limit was $1000-1200 \mathrm{~m}$. Accuracy for F12 was $\pm 1.0-1.3 \%$ for the three cruises.

\section{Water masses}

Persian Gulf Water Similar to historical data, the salinity maximum in the Gulf of Oman was found at $300 \mathrm{~m}$ depth (densities around $\sigma_{\Theta}=26.6$ ). The salinity maximum (38.5) was most pronounced in the northwestern part of the Gulf and decreased farther south. At $16^{\circ} \mathrm{N}$ the maximum was 35.80 at a density of $\sigma_{\Theta}=$ 26.6. The salinity maximum corresponds to an oxygen maximum, with the highest oxygen saturations $(50 \%)$ found in the Gulf of Oman. This reflects the recent contact of PGW with the surface.

The F12 concentrations in the salinity maximum at $\sigma_{\Theta}=26.6$ exceeded the surface concentrations by a factor of 2-2.7 (Figure 2a). The signal was most pronounced at the near coastal westernmost stations, reaching $270 \%$ (Figure 2) at about $300 \mathrm{~m}$ depth. The saturations have been calculated using the atmospheric data of Weiss et al., [pers. comm.] and the solubility function of Warner and Weiss, [1985]. These supersaturations were also found in August 1995 (R.Fine, pers. comm.). At the exit of the Gulf of Oman, the intermediate F12 maximum decreased to about $100 \%$ saturation. Oversaturations exceeding $120 \%$ are in general not observed in open ocean water. The outflow of the Persian Gulf might have been contaminated with oil. The CFCs

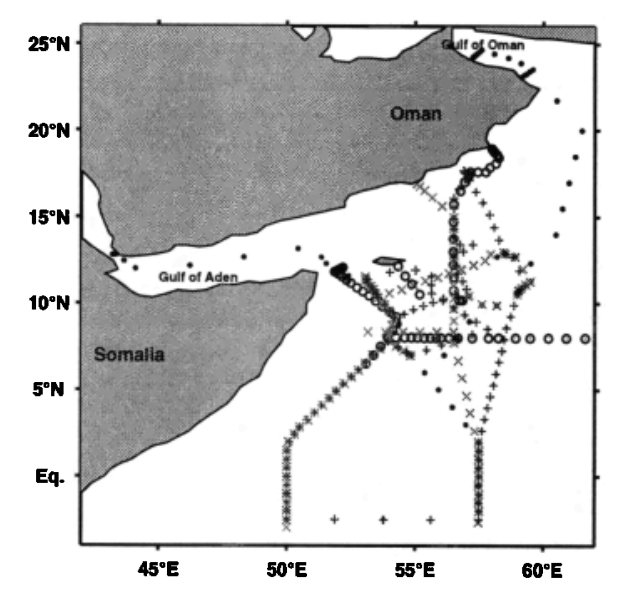

Figure 1. Station map, WOCE cruises RV 'Sonne' 89, August 1993 (o), and the RV 'Meteor' cruises M32/1, March - April 1995 (•), M32/4, June - July 1995 (x), and M32/6, August - September $1995(+)$. 

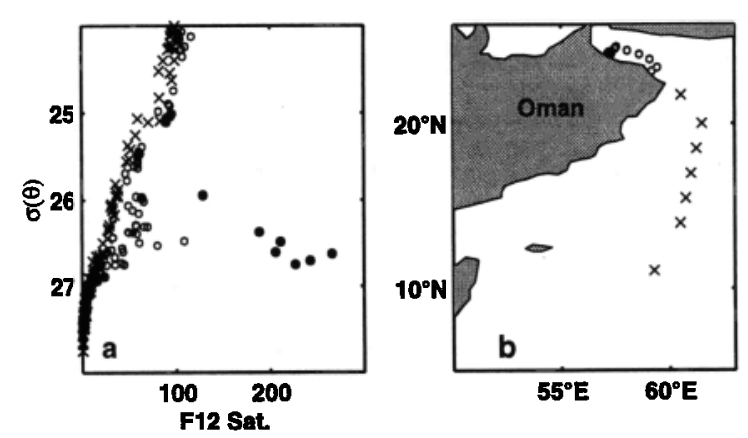

Figure 2. (a) F12 saturation (\%) vs $\sigma_{\Theta}$ of the Gulf of Oman and the Arabian Sea north of $12^{\circ} \mathrm{N}$, April 1995. The symbols in (b) correspond to the symbols in (a).

are lipophilic, and the presence of oil could be responsible for these exceptionally high concentrations in the PGW.

In the density range $\sigma_{\Theta}=26.0-26.9$ on the meridional section through the Arabian Sea (Figure 3), the F12 positive anomalies south of $2^{\circ} \mathrm{N}$ and north of $12^{\circ} \mathrm{N}$ are about of equal strength. This is an indication, that despite the observed F12 supersaturations in the Gulf of Oman, the CFC budget of the Arabian Sea in this density range is dominated by two sources, the PGW, and by the inflow of ICW.

Red Sea Outflow The RSW forms the broad salinity maximum in the Arabian Sea at $\sigma_{\Theta}=27.0-27.8$. At the Strait of Bab el Mandeb, the F12 saturation in the outflow was $65 \%$ at $\sigma_{\Theta}=27.2(400 \mathrm{~m}$ depth). The saturation decreased to $50 \%$ while descending to depths around $800 \mathrm{~m}$. There the oxygen saturation is low at $23 \%$. The low saturations are not surprising, the outflow contains deep and intermediate water masses from the Red Sea which were isolated from the surface for some time. The intermediate CFC maximum is barely visible outside the Gulf of Aden (Figure 4). The salinity signal however has been observed as far south as the Agulhas Current [Gordon et al.,1987].

In the F12 anomaly plot (Figure 5) it is evident, that for the density range $26.9-27.5$, the RSW is the main source for the CFC budget in the Arabian Sea. The ICW in this density range is characterized by a negative F12 anomaly. Note that the anomalies shown here are different from Figure 3 because the mean F12 profile for the two sections are different.

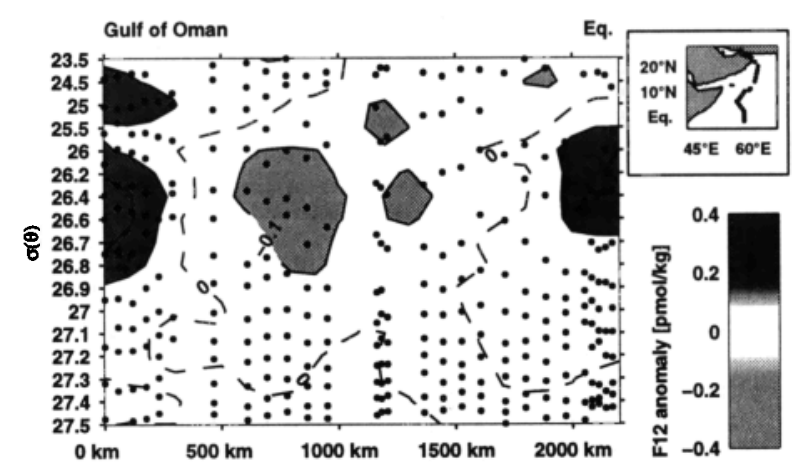

Figure 3. F12 anomaly ( $\mathrm{pmolkg}^{-1}$ ) on density surfaces along the section indicated in the inset map, April 1995. The anomaly was calculated by subtracting the mean F12 profile of the section.
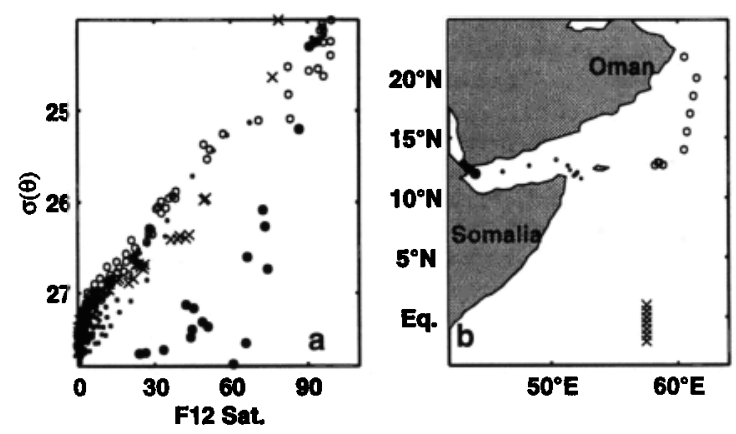

Figure 4. (a) F12 saturation (\%) vs $\sigma_{\Theta}$ (b) of the Gulf of Aden and the Arabian Sea, April 1995. The symbols in (b) correspond to the symbols in (a).

Indian Central Water The third source water mass for the intermediate layer of the Arabian Sea is the ICW, which is formed south of $40^{\circ} \mathrm{S}$ [You and Tomczak, 1993]. These authors found the contribution of other water masses in the equatorial region west of $80^{\circ} \mathrm{E}$ to be smaller than $10 \%$. The characteristic of ICW is inferred from our measurements south of the equator $\left(0^{\circ}-\right.$ $\left.3^{\circ} \mathrm{S}\right)$. The T-S correlations of typical stations located south and north of the equator highlight the influence of the high salinity intermediate water masses (Figure $6)$.

North of $15^{\circ} \mathrm{N}$, the inflow of PGW leads to a salinity maximum in the density range $\sigma_{\odot}=26.5-27.0$. Below $\sigma_{\Theta}=27.0$, the salinity distribution north of $2^{\circ} \mathrm{N}$ is dominated by the RSW. Even south of the equator, the linear T-S correlation of the ICW is disturbed by the salinity imprint of the RSW. Thus the inferred CFC signal of ICW might also be influenced by the RSW. The characteristic of ICW between the equator and $3^{\circ} \mathrm{S}$ is presented for two different density ranges, $\sigma_{\Theta}=26.5$ 27.0 and $\sigma_{\Theta}=27.0-27.4$, roughly the depth ranges from $300 \mathrm{~m}$ to $500 \mathrm{~m}$ and from $500 \mathrm{~m}$ to $1000 \mathrm{~m}$ (Tables $1 \mathrm{a}, \mathrm{b})$.

The upper limit of $300 \mathrm{~m}$ was chosen to be well below the influence of the monsoonal upwelling and deepening of the mixed layer, assuming that no CFCs enter the depth range below $300 \mathrm{~m}$ directly from above. The lower limit corresponds roughly to the CFC detection limit in the Arabian Sea. In August-September 1995 (M32/6), the CFC and oxygen saturations of ICW in the density range $\sigma_{\Theta}=26.5-27.0$ were generally higher than

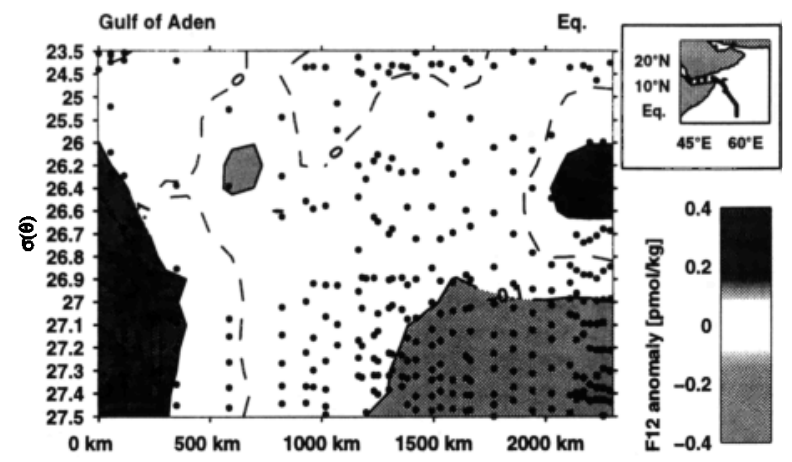

Figure 5. F12 anomaly $\left(\mathrm{pmolkg}^{-1}\right)$ on density surfaces along the section indicated in the inset map, April 1995. The anomaly was calculated by subtracting the mean $\mathrm{F} 12$ profile of the section. 


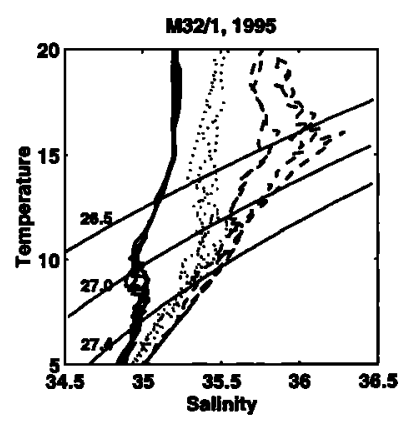

Figure 6. T-S characteristic of typical stations located south of the equator (solid lines), between $8^{\circ} \mathrm{N}-9^{\circ} \mathrm{N}$ (dotted) and north of $15^{\circ} \mathrm{N}$ (dashed), April 1995.

during the previous cruises in June-July (M32/4) and March-April (M32/1). In addition, CFC and oxygen saturations were usually higher on the western track than on the eastern track (Table 1, for locations see Figure 1), due to the inflow of 'younger' ICW along the western boundary.

Intermediate layer of the Arabian Sea The gas saturations of the intermediate layers of the Arabian Sea north of $12^{\circ} \mathrm{N}$ are summarized in Table 2a,b showing similar characteristics during the three cruises. The mean CFC and oxygen saturations at $300 \mathrm{~m}-500 \mathrm{~m}$ depth, during August - September 1995 (M32/6), however, were slightly higher than during the previous cruises, most likely caused by the fresh inflow of ICW in the research area (Table 2a). The oxygen saturations in this layer are significantly lower in the Arabian Sea compared to the source water masses, caused by biological consumption.

Like oxygen, the F12 saturations of the Arabian Sea also do not lie on a mixing line between the respective source water masses, because CFC mixing is not linear due to the transient behaviour of the tracer. For the depth range below $500 \mathrm{~m}$ the inflow of ICW is not the main source for the CFC budget in the Arabian Sea (Table 2b). The CFC saturations in the Arabian Sea are slightly higher than in the ICW, reflecting the impact of the higher CFC concentrations of RSW. The oxygen saturations are again lower than the saturations of the inflowing water masses.

\section{ICW inflow into the Arabian Sea}

A simple model is developed, which estimates the inflow of ICW into the Arabian Sea north of $12^{\circ} \mathrm{N}$ by simulating the observed CFC concentrations in 1995 (from the three 'Meteor' cruises), in 1993 (RV 'Sonne' data, see Figure 1), and in 1987 [Olson et al., 1993]. The in-

Table 1. Gas saturations (\%) of ICW south of the equator, $\sigma_{\Theta}=26.5-27.0$ (a) and $\sigma_{\Theta}=27.0-27.4$ (b) for the eastern and western tracks (see Figure 1)

\begin{tabular}{ccccccc}
\hline M32 & F12 & $\begin{array}{c}\text { F12 } \\
\text { leg }\end{array}$ & $\begin{array}{c}\text { east } \\
\text { west }\end{array}$ & $\begin{array}{c}\text { east } \\
\text { west }\end{array}$ & $\begin{array}{c}\mathrm{O}_{2} \\
\text { east }\end{array}$ & $\begin{array}{c}\mathrm{O}_{2} \\
\text { west }\end{array}$ \\
\hline a)1 & 20.5 & - & - & - & 32.0 & - \\
a)4 & 19.6 & 21.2 & 19.0 & 20.8 & 32.9 & 37.9 \\
a)6 & - & 23.0 & - & 23.4 & 42.1 & 39.5 \\
b)1 & 3.0 & - & - & - & 18.0 & - \\
b)4 & 2.7 & 2.9 & 2.4 & 3.0 & 17.0 & 18.0 \\
b)6 & - & 3.2 & - & 2.9 & 18.4 & 19.5 \\
\hline
\end{tabular}

Table 2. Gas saturations (\%) of the Arabian Sea north of $12^{\circ} \mathrm{N}, \sigma_{\Theta}=26.5-27.0(\mathrm{a})$ and 27.0-27.4 (b)

\begin{tabular}{cccc}
\hline M32 & $\begin{array}{c}\mathrm{F12} \\
\text { leg }\end{array}$ & $\begin{array}{c}\mathrm{F} 11 \\
\%\end{array}$ & $\begin{array}{c}\mathrm{O}_{2} \\
\%\end{array}$ \\
\hline a)1 & 14.0 & - & 3.6 \\
a)4 & 12.4 & 12.9 & 4.5 \\
a)6 & 16.2 & 15.1 & 5.5 \\
b)1 & 3.8 & - & 2.7 \\
b)4 & 3.5 & 3.3 & 3.5 \\
b)6 & 4.5 & 4.1 & 3.4 \\
\hline
\end{tabular}

termediate layers of the Arabian Sea north of $12^{\circ} \mathrm{N}$ are divided in two well mixed boxes ranging from $300 \mathrm{~m}$ to $500 \mathrm{~m}$ depth, corresponding to density levels $\sigma_{\Theta}=26.5$ - 27.0 (Box 1) and from $500 \mathrm{~m}$ to $1000 \mathrm{~m}$ depth, corresponding to density levels $\sigma_{\odot}=27.0-27.4$. (Box 2). Box 1 covers the influence of PGW and Box 2 the influence of RSW. It is assumed, that CFCs could only enter the model area by inflow of PGW, RSW, and ICW. Mass is conserved, and the outflow from the Arabian Sea carries the mean concentration of the boxes. Thus the model can only detect inflows which stay north of $12^{\circ} \mathrm{N}$ long enough to completely mix within the model area. The integration is forward in time and starts in 1935 with a CFC free ocean, the time step is one year.

We assume that $0.18 \mathrm{~Sv}$ PGW [Koske, 1972] enter Box 1 with F12 saturation of $100 \%$, and ranging from 80 to $140 \%$ in various model runs. RSW only enters into Box 2 , and the flow varied from 0.2 to $0.4 \mathrm{~Sv}$. Since RSW is formed outside of the Arabian Sea, only a fraction of the total RSW transport of about $0.4 \mathrm{~Sv}$ [Siedler, 1968] is likely to enter the model area. The CFC saturation of RSW is set to $50 \%$ as observed just east of the Strait of Bab el Mandeb. The saturations of PGW and RSW remain constant throughout the time period from 1935 to 1995 , because they enter the Arabian Sea shortly after formation, and we assume that the formation of RSW and PGW remains constant over the time period. The CFC saturations of the ICW in 1995 flowing in Box 1 and Box 2 were inferred from Table 1. The ICW is formed remote from the Arabian Sea, and the saturations observed between $0^{\circ}$ and $3^{\circ} \mathrm{S}$ are modified by mixing of different 'vintages' of ICW. Thus, the saturations were assumed to decrease by $0.5 \%$ per year [Beining and Roether, 1996]. The ICW inflows which produce F12 concentrations in the Arabian Sea comparable to the observations in 1987, 1993, and 1995 are taken as valid solutions (Figure $7 \mathrm{a}, \mathrm{b}$ ).

With increasing F12 saturations for PGW, the model derived ICW inflow decreases rapidly from $0.5-1.2 \mathrm{~Sv}$ at $80 \%$ saturation to $0-0.2 \mathrm{~Sv}$ at $140 \%$ saturation. If PGW saturations observed in $1995(270 \%)$ were representative of the entire time period from 1935 - 1995, the mean F12 concentrations in the Arabian Sea would be significantly higher than observed. The mean temperature and salinity values of the inflows and the model area (not shown) point to a PGW/ICW ratio of $1: 1.9$, i.e. an ICW inflow of $0.34 \mathrm{~Sv}$ for Box 1.

The required ICW inflow into Box 2 is strongly dependent on the RSW inflow into the Arabian Sea north of $12^{\circ} \mathrm{N}$. With a RSW flow of $0.3 \mathrm{~Sv}$, the maximum ICW inflow required by the model is $3 \mathrm{~Sv}$, with a ventilation time (volume exchange of Box 2 through RSW and ICW) of 17 years. A RSW flow of $0.4 \mathrm{~Sv}$ leads to a maximum ICW inflow of $6 \mathrm{~Sv}$. The mean temperature and salinity values give a RSW/ICW ratio of 1:2.9, i.e. 

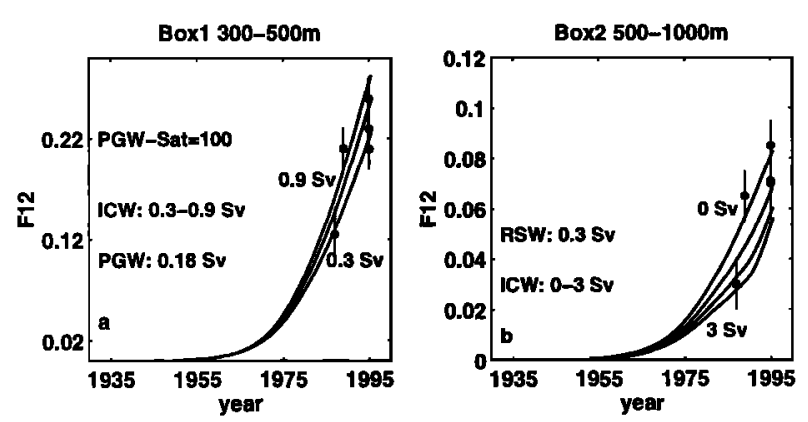

Figure 7. (a) Temporal evolution of the F12 concentration in the Arabian Sea, Box 1, $\sigma_{\Theta}=26.5-27.0$, modeled with different inflow of ICW (0.3-0.9 Sv), PGW saturation is $100 \%$. (b) Temporal evolution of the F12 concentration in the Arabian Sea, Box 2, $\sigma_{\Theta}=27.0$ 27.4, modeled with different inflow of ICW (0-3 Sv). The RSW inflow is $0.3 \mathrm{~Sv}$. The dots with error margins are the observations from 1987, 1993, and 1995.

$0.3 \mathrm{~Sv}$ RSW need an ICW inflow of $0.9 \mathrm{~Sv}$, corresponding to the lower limit of the CFC model estimates. If the F12 saturation of RSW is assumed to be $100 \%$ and the flow to be $0.4 \mathrm{~Sv}$ as has been done by Olson et al., [1993], ICW inflows between 6 and $13 \mathrm{~Sv}$ into Box 2 are required by the model to balance the $\mathrm{F} 12$ budget in the Arabian Sea. The latter authors choose this unrealistic high saturation value because observations at that time were lacking.

\section{Conclusions}

Hydrographic data for the intermediate water masses of the Arabian Sea are sparse. The CFC data turned out to provide additional insight into the characteristics of the Red Sea and Persian Gulf outflows as well as on the northward transport of ICW across $12^{\circ} \mathrm{N}$ into the Arabian Sea. The estimated inflow of ICW of 1 to $6 \mathrm{~Sv}$ into the Arabian Sea north of $12^{\circ} \mathrm{N}$ is small compared, for instance, to the transports associated with the Great Whirl and Socotra Gyre system [eg Fischer et al., 1996]. Nevertheless, these strong current features are mainly restricted to the upper $300 \mathrm{~m}$. This was not the case in the $1000 \mathrm{~m}$ deep Abd al Kuri - Somalia passage at $12^{\circ} \mathrm{N}$ in August 1993. Fischer et al. [1996] observed a constant northward flow from $200 \mathrm{~m}$ to $1000 \mathrm{~m}$ of 30 $\mathrm{cm} / \mathrm{s}$ with a small southward component of RSW on the western side of the passage. In 1995 and 1996 this throughflow showed a net northward transport from top to bottom mainly between 0 and $5 \mathrm{~Sv}$ [Schott et al.,
1997]. This deep passage therefore could serve as the main exchange path of ICW to the Arabian Sea north of $12^{\circ} \mathrm{N}$ with transports similar to the exchange modeled here and at the same time serve for a southward leakage of RSW on the western side of the passage.

Acknowledgments. We thank captain and crew of RV Meteor for their support during the field measurements. Funding was provided by BMBF, grant 03F0157A. The $M e-$ teor cruises were supported by the DFG.

\section{References}

Beining, P., and W. Roether, Temporal evolution of CFC 11 and CFC 12 concentrations in the ocean interior, $J$. Geophys. Res., 101, 16455 - 16464, 1996.

Fischer, J., F. Schott, and L. Stramma, Currents and transports of the Great Whirl - Socotra Gyre system during the summer monsoon, August 1993, J. Geophys. Res., 101, 3573-3587, 1996.

Gordon, A.L., J.R.E. Lutjeharms, and M.L. Gründlingh, Stratification and circulation at the Agulhas Retroflection, Deep Sea Res., 34, 565-599, 1987.

Koske, P.H., Hydrographische Verhältnisse im Persischen Golf aufgrund von Beobachtungen von FS Meteor im Frühjahr 1965, Meteor Forschungsergebnisse Al1, 58-73, 1972.

Olson, D., G.L. Hitchcock, R. Fine, and B.A. Warren, Maintenance of the low oxygen layer in the central Arabian Sea, Deep Sea Res., 40, 673-685, 1993.

Quadfasel, D., and F. Schott, Watermass distributions at intermediate layers off the Somali coast during the onset of the southwest monsoon, J. Phys. Oceanogr 12, 1358$1372,1982$.

Schott, F., J. Fischer, U. Garternicht, and D. Quadfasel, Summer monsoon response of the northern Somali Current, 1995, Geophys. Res. Lett., this issue, 1997.

Siedler, G., Schichtungs- und Bewegungsverhältnisse am Südausgang des Roten Meeres, Meteor Forschungsergebnisse A4, 1-76, 1968.

Warner, M.J., and R.F. Weiss, Solubilities of chlorofluorocarbons 11 and 12 in water and seawater, Deep-Sea Res. 32, 1485-1497, 1985.

Wyrtki, K., Physical Oceanography of the Indian Ocean, The Biology of the Indian Ocean, B.Zeitschel, and S.A. Gerlach, eds., Springer Verlag, Berlin 18-36, 1973.

You, Y., and M. Tomczak, Thermocline circulation and ventilation in the Indian Ocean derived from water mass analysis, Deep Sea Res., 40, 13-56, 1993.

(Received January 17, 1997; revised March 26, 1997; accepted April 2, 1997.) 